\title{
CAPITALISM, GLOBALIZATION, AND EPOCHAL SHIFTS: AN EXCHANGE
}

\author{
by A. SIVANANDAN
}

Ellen Meiksins Wood wants to know what is epochal about the shift in capitalism wrought by the new technologies (Monthly Review July/August 1996). Capitalism, she maintains, is still capitalism and is still bent on "extracting more value from labor"-only now, "the logic of the old mass production economy" can be "diversified and extended," reaching "whole new sectors" and affecting "types of workers more or less untouched before."

What is it but epochal:

-when the whole of the industrial working class has been disaggregated, de-skilled and re-composed into highlyskilled "core" workers at one end of the production process, and unskilled or semi-skilled "peripheral" workers at the other?

-when factories, which once housed thousands of workers under one roof, are no longer fixed in time or place, but are stretched across the world in global assembly linesand capitalism, instead of importing labor, can take up its plant and walk to any part of the world where labor is cheap and captive and plentiful;

A. Sivanandan is author of Communities of Resistance (Verso, 1991) and When Memory Dies (Arcadia, 1997) and the distinguished editor of Race and Class, 120-126 Lavender Avenue, Mitcham, Surrey CR4 3HP, UK. 
-when, as a result, working-class organizations have become fragmented or been destroyed altogether, and the working-class movement rendered impotent, and

- thereby removing that tension between Capital and Labor which once produced not only social reforms such as the factory acts, the education acts and the public health acts but also the so-called bourgeois freedoms of speech, of assembly, and of universal suffrage-while engendering, at the same time, the values and mores of solidarity and community and fellowship;

-when governments owe their power not to the voters, but to business conglomerates, media moguls, owners of the means of communication, who massage the votes, manipulate the voters-and governments go where multinationals take them, to institute policies at home or set up regimes abroad that are hospitable to global capital. (Ms. Wood, of course, has doubts about "the growth of multi-national corporations" and the "weakness of the nation state");

-when, as a consequence, the bourgeoisie of the Third World is no longer a national bourgeoisie working in the interests of its people but an international bourgeoisie working in the interests of international capital. (Ms. Wood accepts that capitalism, for the first time, has become "a truly global phenomenon," though she disdains "the tired old formula, "globalization"”);

-when the "knowledge workers" who run the Information Society, who are in the engine room of power, have become collaborators in power.

I could go on, but the point I want to make-at the risk of appearing technologically determinist-is that the qualitative changes brought about at the level of the forces of production have brought about changes in the mode of production which, in turn, have led to changes in social relations. If "the handmill gives you society with the feudal lord and the steam-mill gives you society with the industrial capitalist," the microchip gives you society with the global capitalist. To insist, as Ms. Wood does, that the emphasis should be on "the logic of capitalism, not some particular technology or labor process but the logic of specific social 
property relations" is to overlook the way that such technology or labor process have altered social property relations. (Whatever happened to Braverman?).

Doubtless capitalism is capitalism is capitalism, but the failure to distinguish between its different avatars freezes us in modes and forms of struggle which are effete and ineffectual, and blinds us to the revolutionary possibilities opened up by information technology. By the same token, it fails to see the dangers posed by the "culture of postmodernism" which is organic to information capitalism, and not some sort of psychological mutation spawned in the aftermath of the post-war boom.

If I take passionate issue with Ms. Wood, it is because I am concerned that, in recoiling from the post-Marxist heresies all around us, we ourselves do not overbalance into an abstract, academic Marxism which does not speak to the everyday struggles of people in their fight for survival against a marauding capitalism.

\title{
A Reply to A. Sivanandan
}

\author{
by ELLEN MEIKSINS WOOD
}

"Globalization" or "Globaloney"?

I'm sorry that my piece on postmodernity has aroused such anger in A. Sivanandan. Since I have great respect for him and, as far as I know, we're generally on the same side, I must have communicated very badly to have generated such passionate disagreement. Still, I think that miscommunication is only part of the problem. I think he has missed not only the point of my argument but, more importantly, the point of our present historical moment. 
Sivanandan's main objection seems to be that I treat capitalism as a single, never-changing system. In fact, my argument was rather that capitalism is an ever-changing system.

This means that, while we track the endless processes of change in this uniquely dynamic system, we have to be very clear about what defines capitalism as a specific social form throughout all its transformations. We have to be very clear not only about what changes but about what stays the same: the unique systemic logic of capitalism, the specific "laws of motion" or "logic of process" common to capitalism in all its forms - the very logic that generates those constant changes.

I argued that histories of capitalism like those contained in some theories of "postmodernity" focus on the discontinuities within capitalism while playing down the discontinuities between capitalism and other social forms. So instead of emphasizing the distinctive specificity of capitalism's laws of motion and the historic transformations that brought it about, they tend to take capitalism for granted, as if it were the natural outcome of universal, transhistorical laws-typically the laws of technological development. This contributes, I think, to some fairly significant misunderstandings of what is happening to capitalism today.

Sivanandan is a case in point. Some of the changes he catalogues don't sound to me like specific features of the "postmodern" condition. They seem more like general and long-term processes that have been part of capitalist development from the beginning, the constant technological changes driven by the pressures of competition and profit-maximization, the constant recomposition of capital and labor and the class relations between them. The question, then, is whether there has been a qualitative leap in the "postmodern" period, a seismic shift in the nature of capital and labor which represents a major epochal transition.

In my discussion of postmodernity, I left open the possibility that some kind of epochal shift has indeed taken place, but I questioned the account of that shift associated with the idea of "postmodernity." Sivanandan gives us an admirably lucid summary of the kind of thing I was objecting to: "the 
microchip," he tells us, "gives you society with the global capitalist." The new technologies have inevitably given rise to a new kind of capitalist system, with "global assembly lines," an "international bourgeoisie" and freely mobile capital which can "walk to any part of the world where labour is cheap and captive and plentiful," bypassing the nation-state and leaving in its wake an essentially powerless working class (if, indeed, such a working class can still be said to exist at all).

So the epochal shift Sivanandan has in mind can be summed up under the rubric of "globalization." In my original article, I mentioned only in passing my objections to what I called that "tired" idea of globalization (Sivanandan contemptuously dismisses my doubts about it) and my preference for describing the current historical moment as, maybe, the "universalization" of capitalism. I've elaborated on some of those objections in a longer version of the postmodernity piece which is being published elsewhere, ${ }^{1}$ but I'll try very briefly to outline a few of these and some other objections in the short space I have here.

Let me say this right up front: I think the concept of "globalization" as it is commonly understood is the heaviest ideological albatross around the neck of the left today. In the conventional wisdom about globalization, the left now occupies the same ground as the neo-liberal right, in a historically unprecedented kind of ideological alliance. This conventional wisdom (or what one or two comrades have called "globaloney" ) serves as an excuse for the most complete defeatism and for the abandonment of any kind of anti-capitalist project. In the current conception of globalization, left joins right in accepting that "There Is No Alternative"-not just no alternative to capitalism but no alternative to a more or less (the right goes for more, the left somewhat less) ruthlessly "flexible" capitalism. ${ }^{3}$

Now if that conception of globalization really did more or less accurately describe what's happening in the world today, and if it really did correctly identify the limits now imposed on political action, then my ideological objections wouldn't count for very much. I and other socialists would just have to put our ideological preferences aside, swallow hard, 
and accept the unhappy truth that the socialist project is dead, or at best that it cannot in any foreseeable future amount to more than a timid tinkering at the edges of capitalism. But there are many reasons to doubt that "globalization," at least in the conventional meaning of the term, does represent an accurate account of the present historical moment. There are good reasons to treat it as an ideological mystification. And there are very good reasons to doubt that the socialist project has to be circumscribed in the specific ways suggested by "globalization."In fact, some of the assumptions generally associated with that idea are so misleading that the use of the word itself may be getting in the way of understanding what is really going on.

There are two separate questions here. The first is whether the developments that conventionally go under the name of globalization-which Sivanandan eloquently enumerates-are nearly as advanced and widespread as he and others think they are and whether they have the consequences people think they have. The second is whether those developments that have actually occurred are best described by the term "globalization," or whether the assumptions underlying the concept of globalization are misleading and disguise more than they reveal about the changes we are living through today.

On the first question, I can make only a couple of points here. There have been other articles, in Monthly Review and elsewhere, that make these points much better than I can do. ${ }^{4}$ My remarks on this question will rely very heavily on the work of Harry Magdoff, who will, I hope, soon commit his latest thoughts on these matters to print in Monthly Review.

First, a few simple facts. No one can doubt that, while capitalism has always tended toward internationalization, production has become increasingly internationalized in the past two decades. But let's put things into perspective: foreign branches of multinational corporations account for about 15 percent of the world's industrial output, while 85 percent is produced by domestic corporations in single geographical locales. ${ }^{5}$ While finance capital moves freely across national boundaries by electronic means, industrial capital isn't nearly 
as mobile; and such mobility as it does have doesn't unambiguously conform to Sivanandan's picture. For instance, in 199378.9 percent of U.S. foreign direct manufacturing investment was in other advanced capitalist countries: Canada, Europe, Australia, and Japan. Investment in pursuit of cheap, unskilled, and unregulated third world labor certainly takes place, and I have no intention of underestimating the importance of this tendency-which, of course, follows the logic of capitalist exploitation as it has operated since the beginning. There may be evidence that this trend has accelerated more recently, but there are also signs that it can recede as well as advance, in accordance with prevailing economic conditions. Nor does even this type of investment neatly fit the "globalization" model. For example, the conventional model seems to assume that investment in cheaper and less regulated labor markets directly replaces production at home. But the majority of the goods produced in such labor markets as a result of U.S. direct manufacturing investment are for local consumption, not sold in the United States. And U.S. manufacturing production occurs overwhelmingly in the United States, on a much larger scale than several decades ago: domestic manufacturing production is five times greater than it was, say, in 1950.

None of this makes capitalism less vicious (did Sivanandan really mean to suggest that, before globalization, the "national bourgeoisie" used to work "in the interests of its people"?). Nor does it deny that new technologies, like earlier technological changes, can facilitate new methods of exploitation. And it certainly doesn't argue against the current crisis and stagnation of capitalism, the destructive effects of deregulation, downsizing, mass unemployment, increasing poverty, or the attacks on social provision. It does mean, though, that we may have to look elsewhere for an explanation of the long-term structural crisis of capitalism than in simplistic formulas about "globalization." What people are calling "globalization" may be more an effect than a primary cause.

Having mentioned these facts and figures, I'm not going to pretend that I know where things are going. My point here is just this: Personally, I find these simple facts remarkable, if 
only because they are so contrary to what the hype of globalization leads us to expect. So I mention them mainly to illustrate how easily the conventions about globalization can disguise some very basic facts about the world in which we live.

\section{Class and State in a "Globalized" Capitalism}

More politically important, though, are the assumptions about state and class power that are typically linked with propositions about the internationalization of production and the mobility of capital. Basically, these assumptions come down to this: the more "global" capital is, the less the state can do; and, while the working class is ever more fragmented, power has passed to a transnational capitalist class united in a variety of supranational organizations. This new global order, the argument usually goes, has effectively ended the socialist project as anything more than a better and maybe more humane management of "flexible" capitalism.

Let me take the point about international capital first.

It is true that there are now more giant corporations with a global reach than ever before, and there are now more international organizations like the IMF or the World Bank serving the interests of capital. But to acknowledge this is very far from saying that there exists a unified international capitalist class or any organization that serves as a kind of capitalist international. After all, if anything has been "globalized," if there is any truly international economic force, it is the market itself. What does this mean if not the internationalization of competition? Like all capitalist processes, this one is contradictory in its effects. "Globalization" in this respect may mean new forms of capitalist integration and cooperation across national boundaries, but it also means that a growing number of national and regional capitalists are compelled to enter into active competition with each other. It even means that, as national economies become more open to capital from outside, domestic capitalists are drawn into new forms of competition with each other, over the benefits to be derived from inward investment.

So the "global" economy if anything may mean less not more capitalist unity. Although it's far too early to make any 
confident pronouncements about the direction and consequences of "globalization," it seems reasonable to say that, far from integrating capital, it's at least as likely to produce disintegrative effects. At any rate, the internationalization of the market is hardly an unambiguous advantage to capital. The increasing exposure of capital to the international forces of the market is at least as much a point of vulnerability as a source of strength.

What conclusions should the socialist left draw from this? Probably just the opposite of the conclusions to which the conventional idea of "globalization" is pushing us. This idea invites us to one or both of the following political conclusions: that, in the context of globalization, only the most particular and fragmented struggles are possible (e.g. the "politics of identity"), not really against capitalism but within its interstices; and/or that the only effective anti-capitalist struggles would have to be organized internationally. Either of these is tantamount to saying that no effective anti-capitalist struggle is possible at all. I think, in fact, that these propositions are intended as concessions of defeat.

Of course an internationalist perspective remains vital to any socialist movement, and no socialist project is conceivable to me that is not expressed in, and reinforced by, working class solidarity across national frontiers. It would also be foolish and counter-productive for the socialist left not to do its utmost to capture the terrain now occupied by transnational capitalist organizations like the European Union. But the main arena of organization and struggle - in fact, the main channel into international struggles-will still have to be local and national. At the same time, if local and national struggles are to be at all effective in confronting capital, the various fragments of opposition will have to be integrated into a unified politics of class.

Capitalism, in its constant recomposition of the working class, has always divided and redivided that class in various ways. In that sense, the fragmentation to which Sivanandan refers is not a product of "globalization" but a continuation and expansion of processes that have always been inherent in capitalism. By the same token, class politics has always 
required an effort to create unity out of many differences. So if the processes of class fragmentation have today been intensified and expanded, then the effort to create unity out of difference has to be intensified and expanded too. This means, among other things, that class organizations have to be more attuned than ever before to "special oppressions"especially racial and sexual oppressions-and more involved in the struggles against them, both because these struggles are important in themselves and because they are necessary to the construction of class solidarity. So to me the current fragmentation of the working class doesn't mean that we live in an entirely new era in which the "politics of identity" has to replace the politics of class. On the contrary, it means that, in the face of a "totalizing" capitalist system, the main organizational energies of the left must now more than ever be devoted to constructing a unified class politics on the local and national level.

If the concept of "globalization" leads us to believe otherwise, that is reason enough to get rid of it. It's even arguable that the current "global" economy makes local and national class organization and struggle more rather than less important and potentially more rather than less effective. For one thing, the vulnerability of national capitals to the international forces of the market gives anti-capitalist struggles potentially new targets.

This brings us to the question of the state. The gospel according to Globaloney is that there is an inverse relation between the internationalization of the economy and the power of the state: the more globalization, the smaller the role of the nation-state. But this proposition fails to take into account the simple fact that "globalization" presupposes the state, and that, while the state may have lost some of its traditional functions, it has gained new ones. To put it simply, the nation-state is the main conduit through which national (or indeed multinational) capital is inserted into the global market.

If anything, the new global order is more than ever a world of nation-states; and if these states are permeable to the movements of capital, that permeability has as its 
corollary,indeed as its condition, the existence of national boundaries and state jurisdictions. ${ }^{6}$

The contrast between today's "global" economy and earlier forms of colonial imperialism should suffice to illustrate the point: the old-style colonies were what they were precisely because they presented no effective geo-political barrier to imperial power. The movement of capital across colonial boundaries was, of course, not just a matter of paper transfers or electronic transmissions but the bodily movement of coercive force. Geo-political borders, in other words, were not only notionally but physically permeable. Today, transnational capital may be more effective than was the old-style military imperialism in penetrating every corner of the world, but it tends to accomplish this through the medium of local capital and national states. It may ultimately rely on a new kind of military imperialism - in fact, the military power of a single nation-state, the last remaining "super-power"-to sustain the sovereignty of the market; but it depends on many local political jurisdictions-on, say, the Indian or Chinese stateto maintain the conditions of economic stability and labor discipline which are the conditions of profitable investment. ${ }^{7}$ And every new opportunity for transnational cooperation is matched by opportunities for new kinds of inter-imperialist rivalry-in which the nation-state is still the principal agent.

If the state plays such a vital role in sustaining capital in the global market, it would be perverse for the left to abandon the state as a terrain of struggle, while placing its hopes at one extreme in a completely fragmented "identity" politics and/or, at the other extreme, in an unrealistic fantasy of internationalism unmediated by local and national organization and struggle. If the state is the channel through which capital moves in the "globalized" economy, then it is equally the means by which an anti-capitalist force could sever capital's lifeline.

The "postmodern" left seems blind to this reality, in large part because it has uncritically accepted the concept of globalization and all its underlying assumptions. In particular, the conventional idea of globalization treats it as an inevitable, 
irreversible, natural process, which, independently of any human will or politics, is inexorably taking over the world. This is, if I may say so, nowhere more obvious than in Sivanandan's technological determinism, according to which "globalization" is the inevitable consequence of technological development: the new electronic technologies make globalization not only possible but necessary. ${ }^{8}$

But "globalization" is not some transhistorical natural process-certainly not if it means things like the withdrawal of the state from regulatory and social welfare functions in the interests of capital mobility and "competitiveness" in the world market. These are the products of policy choices, not the working out of natural laws, not the inevitable destination of history-however much these policies have spread from neo-liberalism across the whole political spectrum.

"Globalization" in this sense is, to be sure, not simply a contingent and arbitrary choice. It is certainly a response to certain structural changes. It is at least in part a response to what I've called the universalization of capitalism. In the days of old-style colonial imperialism, the advanced capitalist rivals struggled over the division and redivision of non-capitalist territories. Today, when virtually the whole world economy is capitalist and when even some former colonies are capitalist competitors, the rules have changed, and so has imperialism. "Globalization" represents policy choices adopted to meet the needs of capital in a global system where all significant economic actors are operating according to the logic of capitalism, just as old-style imperialism represented policy choices in the interests of capital in a largely non-capitalist world.

But if globalization is capital's political response to structural conditions, it follows that there are alternative, socialist ways of responding to the same conditions. If old forms of political action like yesterday's Keynesian regulation are even less adequate today than they were in a less "global" economy, this surely doesn't mean that the scope for political action of any kind has narrowed. It simply means that political action can't just take the form of intervening in the capitalist economy but must increasingly take the form of detaching material life from the logic of capitalism. That is the kind of 
thing the left should be thinking about, instead of allowing itself to be paralyzed by the bogey-man of globalization.

One final word in response to Sivanandan. He berates me for failing "to see the dangers posed by the "culture of postmodernism' to socialist values and beliefs and the threat of a new intellectual 'class' which is organic to information capitalism, and not some sort of psychological mutation spawned in the aftermath of the post-war boom." Maybe I was too flippant in describing the "condition of postmodernity" as a psychological condition afflicting a certain sector of the intelligentsia in the capitalist world. That condition is no more and no less "psychological" than any other form of "social being" expressed in social consciousness-in other words, it is indeed an ideological response to specific material conditions, as I've often said before. But I don't find it very helpful or informative to call that culture an expression of "information capitalism" (a formula I find problematic anyway). Its origins go further back to the generational break between those whose intellectual and political formation was rooted in the Depression and in the Second World War, and those who came to intellectual and political maturity in the postwar "golden age" of capitalism, people whose most formative experience was not depression, world war, or the anti-fascist struggle but capitalist expansion and university life. ${ }^{9}$

I do see-very vividly--(and have more than once written about) the dangers posed by the "culture of postmodernism" to socialist beliefs and values. Not the least of those dangers is that intelligent socialists like A. Sivanandan, who have no sympathy for "postmodernism," have nonetheless allowed themselves to be taken in by some of the mythologies that typically go with it.

\section{NOTES}

1. Forthcoming in Review of International Political Economy.

2. I owe this this term to Doug Henwood, who attributes it to Bob Fitch. 
3. For an important discussion of how the myths of globalization are operating across a broad political spectrum and for some alternative proposals, see Greg Albo, "The World Economy, Market Imperatives and Alternatives," Monthly Review Vol. 48, No. 7.

4. See, for example, Doug Henwood Monthly Review Vol. 48, No. 4; Harry Magdoff "Globalization To What End?" A pamphlet from Monthly Review, 1992; L. Panitch, "Globalisation and the State," in R. Miliband and L. Panitch, eds., Socialist Register 1994: Between Globalism and Nationalism (London: Merlin, 1994).

5. See Robert E. Lipsey, Magnus Blomstrom, and Eric Ronstetter, "Internationalized Production in World Output," National Bureau of Economic Research, Inc., Working Paper 5385, December 1995.

6. This discussion is based on my article cited in note 1 .

7. Aijaz Ahmad has made the latter point in an interview published in Monthly Review, Vol. 48, No. 5. For a discussion of the "structural dialectic" of today's imperialism, which includes both the global expansion of capital and the "intensification of the nation-state," see also his "The Politics of Literary Postcoloniality," in Race and Class, 36.3, 1995, especially pp. 10-12.

8. Sivanandan invokes Harry Braverman in support of his appeal to Marx's famous (and much misunderstood) proposition that "the handmill gives you society with the feudal lord and the steam-mill gives you society with the industrial capitalist," just as, according to Sivanandan, the microchip gives you society with the global capitalist. But Braverman practically begins his great book, Labor and Monopoly Capital, with a long discussion of this passage from Marx, the whole point of which is to distance himself from precisely the simplistic, technological-determinist interpretation Sivanandan gives it here.

9. I've discussed this point at greater length in "A Chronology of the New Left, Or: Who's Old-Fashioned Now?” Socialist Register 1995.

\section{MONTHLY REVIEW $\odot$ CANADA}

\section{BUY A NEW OR GIFT SUBSCRIPTION AND PAY ONLY $\$ 36$ Canadian Dollars}




\section{NEW VOICES}

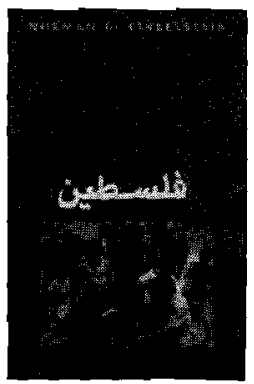

NORMAN G. FINKELSTEIN

The Rise and Fall of Palestine A Personal Account of the Intifada Years

"An American Jewish academician with strong sympathies for Palestinian causes provides a personal perspective on what has been commonly referred to as the intifada. This witness statement is worth critical analysis by a wide range of audiences." Library Journal

"He brings a unique perspective to his subject." Publishers Weekly

"In the best sense of the old term, Norman Finkelstein has fulfilled an obligation to 'witness'." Christopher Hitchens

"Critical and very well informed," Noam Chomsky

"This book is that very rare thing. I do not know any book like it that deals so intimately and yet so clearly with the tragic quandaries of the Palestinian situation." Edward W. Said

$\$ 18.95$ paper (2859-9) 192 pages (1996)

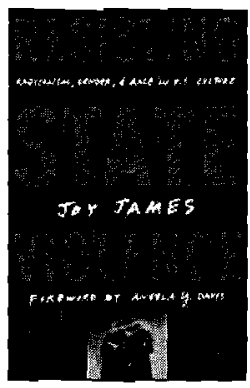

\section{JOY JAMES}

\section{Resisting State Violence}

Radicalism, Gender, and Race in U.S. Culture FOREWORD BY ANGELA Y. DAVIS

"This new collection of essays, tightly woven together and forming a coherent whole, explores the interconnections between violence, political oppression, and U.S. foreign and domestic policies in the contemporary era." Library Journal

"Joy James is among the most thought-provoking, progressive intellectuals in America today. James's analysis points us towards a transformative cultural and political analysis, advancing the struggle for social justice in American society." Manning Marable \$18.95 paper (2813-0) 280 pages (1996)

at bookstores or from

University of Minnesota Press

$1-612-627-1970$

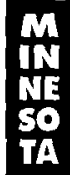

